\title{
Competencies for first year residents - physicians' views from medical schools with different undergraduate curricula
}

\author{
Sophie Fürstenberg ${ }^{1}$, Kristina Schick ${ }^{2}$, Jana Deppermann ${ }^{3}$, Sarah Prediger ${ }^{1}$, Pascal O. Berberat ${ }^{2}$,
} Martina Kadmon ${ }^{3}$ and Sigrid Harendza ${ }^{1,4^{*}}$

\begin{abstract}
Background: Frameworks like the CanMEDS model depicting professional roles and specific professional activities provide guidelines for postgraduate education. When medical graduates start their residency, they should possess certain competencies related to communication, management and professionalism while other competencies will be refined during postgraduate training. Our study aimed to evaluate the relevance of different competencies for a first year resident required for entrustment decision from the perspective of physicians from medical faculties with different undergraduate medical curricula.
\end{abstract}

Methods: Nine hundred fifty-two surgeons and internists from three medical schools with different undergraduate medical curricula were invited to rank 25 competencies according to their relevance for first year residents. The rankings were compared between universities, specialties, physicians' positions, and gender.

Results: Two hundred two physicians participated, 76 from Hamburg University, 44 from Oldenburg University, and 82 from Technical University Munich. No significant differences were found regarding the top 10 competencies relevant for first year residents between the universities. 'Responsibility' was the competency with the highest rank overall. Internists ranked 'Structure, work planning and priorities' higher while surgeons ranked Verbal communication with colleagues and supervisors' higher. Consultants evaluated 'Active listening to patients' more important than department directors and residents. Female physicians ranked 'Verbal communication with colleagues and supervisors' and 'Structure, work planning and priorities' significantly higher while male physicians ranked 'Scientifically and empirically grounded method of working' significantly higher.

Conclusions: Physicians from universities with different undergraduate curricula principally agreed on the competencies relevant for first year residents. Some differences between physicians from different positions, specialties, and gender were found. These differences should be taken into account when planning competence-based postgraduate education training programs.

Keywords: Competence, Curriculum, Internal medicine, Physician, Postgraduate medical education, Residency, Surgery, Undergraduate medical education

\footnotetext{
* Correspondence: harendza@uke.de

${ }^{1}$ Department of Internal Medicine, University Medical Center

Hamburg-Eppendorf, Hamburg, Germany

${ }^{4}$ Universitätsklinikum Hamburg-Eppendorf, III. Medizinische Klinik, Martinistr,

52 D-20246 Hamburg, Germany

Full list of author information is available at the end of the article
} 


\section{Background}

Competencies play an increasing role in postgraduate medical education to define the tasks, which can be entrusted to residents at different stages and levels of their training $[1,2]$. With the CanMEDS model developed by the Royal College of Physicians and Surgeons of Canada, a widely accepted framework based on competencies allocated to seven roles of a physician was established for postgraduate education [3]. Competency-based postgraduate trainings based on CanMEDS have evolved meanwhile in different countries and for different specialties, e.g. internal medicine and surgery $[4,5]$. Canadian directors for postgraduate medical education programs believe though that the CanMEDs roles and their underlying competencies are difficult to teach and assess [6]. In this context, a feasibility study has been performed to develop entrustable professional activities as the basis for assessment of competence [7]. However, the integration of specific competencies (e.g. cultural competency) or competencies required for certain entrustable professional activities into residency training programs for surgery or internal medicine, which are accredited by the Accreditation Council for Graduate Medical Education (ACGME), is not trivial [8, 9] and requires an adaptation in educational culture by the physicians involved as supervisors.

To ease the transition from undergraduate to postgraduate medical training, medical schools are switching from traditional curricula to vertically integrated or competencybased undergraduate medical education [10, 11]. Students from medical schools with vertically integrated curricula needed less time and fewer applications to obtain a residency position and felt better prepared for work and postgraduate training than students who followed a traditional curriculum $[12,13]$. If the CanMEDS framework is used to design a competency-based catalogue of learning objectives for undergraduate medical education, curriculum planners need to be aware that teachers' perceptions of competencies can differ extensively [14]. A ranking study of competencies required for the first year of residency performed among physician educators in the Netherlands and Germany showed full agreement about the top 10 competencies [15]. However, the perspectives on competencies needed for the first year of residency might differ among physician educators according to the curricular structure of the undergraduate training they are used to or according to their specialty or position within a hospital. The aim of our study was to assess whether such differences could be identified between physicians of different specialization and from medical schools with different undergraduate medical curricula.

\section{Methods}

To determine the perspective of teaching physicians on the importance of different competencies for entrustment decisions in first year residents, physicians from three German medical schools with different undergraduate medical curricula participated in this survey. The University Medical Center Hamburg-Eppendorf (UKE) has a vertically integrated undergraduate model curriculum, the Carl von Ossietzky University of Oldenburg has a vertically integrated curriculum in cooperation with the University of Groningen in the Netherlands including repetitive clerkships in the ambulatory setting as of the first training year, and the Technical University of Munich (TUM) has a traditional medical curriculum. In total, 952 physicians (Hamburg: 475, Oldenburg: 204, Munich: 269) from all surgical and internal medicine departments present at the three institutions were approached. An invitation with a link to a questionnaire was sent to the physicians by email. The Ethics Committee of the Chamber of Physicians, Hamburg, confirmed the innocuousness of the study and its accordance with the Declaration of Helsinki. Participation was voluntary and anonymized and participants consented to their participation.

We developed an online questionnaire for the ranking of competencies needed for entrustment decisions in first year residents. We collected sociodemographic data, i.e. physicians' age, gender, position (resident, consultant, supervising attending, department director), and location (Hamburg, Oldenburg, Munich). The residents were not all graduates from the respective medical school. Consultants were board certified specialists with no duties of supervision. Department directors are the heads of the departments who can be substituted by the supervising attendings. Physicians from all four positions are involved clinical work and in teaching activities (lectures, seminars, bedside teaching) in their respective medical school. Their teaching responsibilities are between two and 4 hours a week.

The 25 competencies needed for entrustment decisions in first year residents, which had been defined in an earlier study [16] were placed in random order and their complete definitions [16] were given in an additional window. Instructions for the ranking of the competencies included to drag and drop every competency from the left to the right side of the page and to place them according to their importance for first year residency. Five competencies could be placed in each of the following categories: most important (5 points), very important (4 points), important (3 points), less important ( 2 points), least important ( 1 point). There was no ranking within the five categories. When the ranking was completed, completion of the questionnaire had to be confirmed electronically. Between July and September 2016, the survey was open online for 6 weeks in every location. After two and 4 weeks, a reminder was sent by email. For statistical analysis, the median $(M d n)$ was calculated for each competency for different groups 
(department directors and supervising attendings were merged in one group named "department directors"). When the same median was reached for a competency, the individual rank was given by the underlying mean $(M)$. Due to different sample size within the subjectgroups, non-parametric tests (Mann-Whitney U test and Kruskal-Wallis test) were used to analyze differences.

\section{Results}

Of the 952 physicians who had been contacted to participate in this study, $286(30.0 \%)$ started and 202 (21.2\%) completed the questionnaire. 76 physicians from Hamburg (response rate 15.9\%), 44 from Oldenburg (response rate $21.6 \%$ ), and 82 physicians from Munich (response rate $21.2 \%$ ) completed the questionnaire. Sociodemographic data of the 202 participants including gender, specialty, and position are shown in Table 1. In total, 73 department directors (age: $47.1 \pm 8.4$ years), 34 consultants (age: $39.2 \pm 5.6$ years), and 95 residents (age: $31.5 \pm 3.6$ years) participated.

Table 2 shows the ranking of the competencies relevant for entrustment decisions in first year residents comparing the votes of all physicians according to their university association. No significant differences were found regarding the top 10 competencies between the participating physicians from Hamburg, Oldenburg, and Munich. When all physicians were grouped according to their position (Table 3), consultants were found to rank 'Active listening to patients' $(p<.05)$ and 'Written (and digital) account/report to colleagues and supervisors' $(p<.01)$ significantly higher than department directors and residents, while residents ranked 'Coping with uncertainty' significantly $(p<.05)$ higher than consultants and department directors.

Table 1 Gender, specialty, and position of all participating physicians ( $N=202)$ from Hamburg, Oldenburg, and Munich

\begin{tabular}{lcccccc}
\hline & $\begin{array}{l}\text { Hamburg } \\
(n=76)\end{array}$ & $\begin{array}{l}\text { Oldenburg } \\
(n=44)\end{array}$ & $\begin{array}{c}\text { Munich } \\
(n=82)\end{array}$ \\
\hline Gender & $\mathrm{n}$ & $\%$ & $\mathrm{n}$ & $\%$ & $\%$ & $\mathrm{n}$ \\
$\quad$ Male & 45 & 59.2 & 38 & 86.4 & 60 & 73.2 \\
$\quad$ Female & 29 & 38.2 & 6 & 13.6 & 22 & 26.8 \\
$\quad$ Not specified & 2 & 2.6 & & & & \\
Specialty & & & & & & \\
$\quad$ Surgeons & 20 & 26.3 & 29 & 65.9 & 51 & 62.2 \\
$\quad$ Internists & 56 & 73.7 & 15 & 34.1 & 31 & 37.8 \\
Position & & & & & & \\
$\quad$ Department directors & 24 & 31.7 & 25 & 56.8 & 24 & 29.3 \\
$\quad$ Consultants & 16 & 21.0 & 11 & 25.0 & 7 & 8.5 \\
$\quad$ Residents & 36 & 47.3 & 8 & 18.2 & 51 & 62.2 \\
\hline
\end{tabular}

Grouped according to specialty, among the top 10 competencies, internists attributed significantly higher importance to 'Structure, work planning and priorities' significantly $(p<.05)$ than surgeons while surgeons evaluated 'Verbal communication with colleagues and supervisors' significantly $(p<.05)$ higher than internists (Table 4). Furthermore, internists ranked 'Attention to psychosocial aspects of health problems' significantly $(p<.05)$ higher compared with surgeons. Within the top 10 competencies, women evaluated 'Verbal communication with colleagues and supervisors' and 'Structure, work planning and priorities' significantly $(p<.01)$ higher than men (Table 5). In contrast, men ranked 'Scientifically and empirically grounded method of working' significantly $(p<.01)$ than women.

\section{Discussion}

The top 10 competencies for entrustment decisions in first year residents were not significantly different between physicians from three medical schools with different undergraduate curricula. Our finding is in line with the data from a previous ranking study conducted with clinical educators from two different countries and medical schools with different curricula, which also showed no significant differences among the top 10 competencies [15]. We found $80 \%$ congruency of the 10 key competencies identified in our study with the 10 key competencies found in the ranking study performed with physician educators from two European countries [15] and $90 \%$ congruency with the top 10 competencies of the German cohort from this study [15]. This high level of agreement within a large cohort of physicians from different medical schools on competencies needed by first year residents might be a first step towards a standardization of competency-based medical education and the resulting demand for faculty development with respect to teaching and assessing of competencies [17]. Aspects of management, communication, and professionalism were identified among the top 10 competencies, representing each CanMEDS role except the role of 'Health advocate' [3].

On the other hand, we found significant differences between consultants, department directors and residents regarding the ranking of three competencies. Consultants assessed 'Active listening to patients' and 'Written (and digital) account/report to colleagues and supervisors' significantly more relevant for first year residents than department directors and the residents themselves. In their interaction with residents on the ward, consultants might be more aware than department directors and residents that history-taking alone, which requires active listening to a patient, can lead to the correct diagnosis in more than $80 \%$ [18]. The importance of effective history-taking has also been recognized as a valued 
Table 2 Ranking order of the 25 competencies by all participating physicians

\begin{tabular}{|c|c|c|c|c|c|c|c|}
\hline \multirow[t]{2}{*}{ Competency } & \multirow{2}{*}{$\begin{array}{c}\text { Total } \\
(\mathrm{N}=202) \\
\text { rank }\end{array}$} & \multicolumn{2}{|c|}{$\begin{array}{l}\text { Hamburg } \\
(\mathrm{n}=76)\end{array}$} & \multicolumn{2}{|c|}{$\begin{array}{l}\text { Oldenburg } \\
(\mathrm{n}=44)\end{array}$} & \multicolumn{2}{|c|}{$\begin{array}{l}\text { Munich } \\
(\mathrm{n}=82)\end{array}$} \\
\hline & & rank & Mdn & rank & Mdn & rank & Mdn \\
\hline Responsibility & 1 & 1 & 5 & 1 & 5 & 2 & 5 \\
\hline $\begin{array}{l}\text { Knowing and maintaining own personal } \\
\text { bounds and possibilities }\end{array}$ & 2 & 4 & 5 & 2 & 5 & 5 & 4 \\
\hline Teamwork and collegiality & 3 & 2 & 4 & 3 & 4 & 1 & 5 \\
\hline Empathy and openness & 4 & 5 & 4 & 4 & 4 & 3 & 4 \\
\hline Structure, work planning and priorities & 5 & 3 & 5 & 5 & 4 & 9 & 4 \\
\hline Coping with mistakes & 6 & 6 & 4 & 7 & 4 & 8 & 4 \\
\hline Active listening to patients & 7 & 8 & 3.5 & 6 & 4 & 4 & 4 \\
\hline $\begin{array}{l}\text { Scientifically and empirically grounded } \\
\text { method of working }\end{array}$ & 8 & 7 & 4 & 10 & 4 & 6 & 4 \\
\hline Ethical awareness & 9 & 10 & 3 & 8 & 3.5 & 7 & 4 \\
\hline $\begin{array}{l}\text { Verbal communication with colleagues } \\
\text { and supervisors }\end{array}$ & 10 & 9 & 3 & 12 & 3 & 10 & 3 \\
\hline Advising patients & 11 & 13 & 3 & 9 & 3 & 12 & 3 \\
\hline Safety and risk management & 12 & 14 & 3 & 11 & 3 & 18 & 3 \\
\hline Active professional development & 13 & 11 & 3 & 16 & 3 & 16 & 3 \\
\hline Coping with uncertainty & 14 & 12 & 3 & 17 & 3 & 17 & 3 \\
\hline $\begin{array}{l}\text { Handling emotions of patients and } \\
\text { their relatives }\end{array}$ & 15 & 18 & 2.5 & 13 & 3 & 13 & 3 \\
\hline Adapted informing of patients & 16 & 17 & 3 & 15 & 3 & 11 & 3 \\
\hline $\begin{array}{l}\text { Respecting privacy and autonomy } \\
\text { of the patient }\end{array}$ & 17 & 19 & 2.5 & 18 & 3 & 14 & 3 \\
\hline Attention to individual patient background & 18 & 15 & 3 & 14 & 3 & 15 & 3 \\
\hline $\begin{array}{l}\text { Written (and digital) account/report to } \\
\text { colleagues and supervisors }\end{array}$ & 19 & 16 & $3^{a}$ & 21 & 2 & 19 & 2 \\
\hline Attention to relatives and caregivers & 20 & 21 & 2 & 19 & 2.5 & 21 & 2 \\
\hline Continuity in the care process & 21 & 20 & 2 & 20 & 2 & 22 & 2 \\
\hline $\begin{array}{l}\text { Attention to psychosocial aspects of } \\
\text { health problems }\end{array}$ & 22 & 23 & 2 & 22 & 2 & 20 & 2 \\
\hline Role differentiation & 23 & 22 & 2 & 23 & 1 & 23 & 1 \\
\hline Active health promotion & 24 & 24 & 1 & 24 & 1 & 24 & 1 \\
\hline Financial and social awareness & 25 & 25 & 1 & 25 & 1 & 25 & 1 \\
\hline
\end{tabular}

${ }^{a} p<.05 ;$ ranks $1-10$ are marked in bold

competency for quality patient care in internal medicine residency programs [19]. From their daily practice, consultants seem to be much more aware of the importance of a resident's competency to write reports, as the quality of discharge summaries is often inadequate concerning timeliness, transmission, and content [20]. A meta-analysis of the literature revealed many options to improve the competency of written communication in residency training [21].

Residents ranked 'Coping with uncertainty' significantly higher than consultants and department directors. This competency is not easy to acquire during undergraduate medical training, but residents might observe its importance in daily practice during their training.
Patients' recollections of their symptoms and history, for instance, can be inconsistent when inquired by different physicians [22], which can cause feelings of uncertainty in first year residents who have not encountered this difference during their time at medical school. Consultants might not be aware of this difference to cause anxiety anymore because they have become used to coping with uncertainty in their daily work. Furthermore, residents working on a ward become aware of the necessity to cope with uncertainty in clinical decision making, which will persist even with increasing medical knowledge [23]. Heuristics might help residents to become more confident with their clinical decisions [24] and at the same time convince them that uncertainty may persist 
Table 3 Ranking order of the 25 competencies by all participating physicians according to their position

\begin{tabular}{|c|c|c|c|c|c|c|c|}
\hline \multirow[t]{2}{*}{ Competency } & \multirow{2}{*}{$\begin{array}{c}\text { Total } \\
(\mathrm{N}=202) \\
\text { rank }\end{array}$} & \multicolumn{2}{|c|}{ Department directors $(n=73)$} & \multicolumn{2}{|c|}{$\begin{array}{l}\text { Consultants } \\
(n=34)\end{array}$} & \multicolumn{2}{|c|}{$\begin{array}{l}\text { Residents } \\
(n=95)\end{array}$} \\
\hline & & rank & Mdn & rank & Mdn & rank & Mdn \\
\hline Responsibility & 1 & 1 & 5 & 1 & 5 & 2 & 5 \\
\hline $\begin{array}{l}\text { Knowing and maintaining own personal } \\
\text { bounds and possibilities }\end{array}$ & 2 & 2 & 5 & 3 & 4.5 & 5 & 4 \\
\hline Teamwork and collegiality & 3 & 3 & 4 & 4 & 4 & 1 & 5 \\
\hline Empathy and openness & 4 & 4 & 4 & 2 & 5 & 4 & 4 \\
\hline Structure, work planning and priorities & 5 & 5 & 4 & 5 & 5 & 3 & 5 \\
\hline Coping with mistakes & 6 & 8 & 4 & 9 & 3 & 6 & 4 \\
\hline Active listening to patients & 7 & 9 & 4 & 6 & $4^{a}$ & 8 & 3 \\
\hline $\begin{array}{l}\text { Scientifically and empirically grounded } \\
\text { method of working }\end{array}$ & 8 & 6 & 4 & 11 & 3 & 7 & 4 \\
\hline Ethical awareness & 9 & 7 & 4 & 8 & 3 & 10 & 3 \\
\hline $\begin{array}{l}\text { Verbal communication with colleagues } \\
\text { and supervisors }\end{array}$ & 10 & 13 & 3 & 10 & 3 & 9 & 3 \\
\hline Advising patients & 11 & 10 & 3 & 7 & 3.5 & 13 & 3 \\
\hline Safety and risk management & 12 & 12 & 3 & 14 & 3 & 14 & 3 \\
\hline Active professional development & 13 & 11 & 3 & 18 & 2 & 12 & 3 \\
\hline Coping with uncertainty & 14 & 18 & 2 & 17 & 3 & 11 & $3^{*}$ \\
\hline $\begin{array}{l}\text { Handling emotions of patients and } \\
\text { their relatives }\end{array}$ & 15 & 16 & 3 & 12 & 3 & 15 & 3 \\
\hline Adapted informing of patients & 16 & 17 & 3 & 15 & 3 & 16 & 3 \\
\hline $\begin{array}{l}\text { Respecting privacy and autonomy of } \\
\text { the patient }\end{array}$ & 17 & 15 & 3 & 16 & 3 & 18 & 2 \\
\hline $\begin{array}{l}\text { Attention to individual patient } \\
\text { background }\end{array}$ & 18 & 14 & 3 & 19 & 2 & 17 & 3 \\
\hline $\begin{array}{l}\text { Written (and digital) account/report to } \\
\text { colleagues and supervisors }\end{array}$ & 19 & 20 & 2 & 13 & $3^{b}$ & 19 & 2 \\
\hline Attention to relatives and caregivers & 20 & 19 & 2 & 21 & 2 & 20 & 2 \\
\hline Continuity in the care process & 21 & 21 & 2 & 20 & 2 & 22 & 2 \\
\hline $\begin{array}{l}\text { Attention to psychosocial aspects of } \\
\text { health problems }\end{array}$ & 22 & 23 & 2 & 22 & 2 & 23 & 2 \\
\hline Role differentiation & 23 & 22 & 1 & 24 & 1 & 21 & 2 \\
\hline Active health promotion & 24 & 24 & 1 & 23 & 1 & 24 & 2 \\
\hline Financial and social awareness & 25 & 25 & 1 & 25 & 1 & 25 & 1 \\
\hline
\end{tabular}

${ }^{\mathrm{a}} p<.05,{ }^{\mathrm{b}} p<.01$; ranks $1-10$ are marked in bold

and that it is important to develop the competency to tolerate it during the advancing in postgraduate training.

Among the top 10 competencies, internists ranked 'Structure, work planning and priorities' significantly higher than surgeons. For internists, close interprofessional interaction with nursing staff has been found to involve especially patient management and clinical reasoning competencies [25], which are important qualities to run a ward successfully. In contrast, surgeons ranked aspects of communication significantly higher than internists, which could be related to the great impact communication failures may have on patient safety in the context of surgery [26]. One relevant example for surgical communication supporting patient outcome are team time-outs with checklists implemented in the operating theatre [27]. These differences in competencies relevant for entrustment decisions between internist and surgeons could be relevant when selecting physicians for different residency programs. In our study, female physicians rank competencies regarding management and communication in first year residents significantly higher than male physicians while male physicians rank 'Scientifically and empirically grounded method of working' higher than female physicians. These differences in the assessment of residents' competencies by male and female physicians could imply that supervision of residents might differ between male and female supervisors and it underscores the findings of differences in patient care 
Table 4 Ranking order of the 25 competencies by all participating surgeons and internists

\begin{tabular}{|c|c|c|c|c|}
\hline \multirow[t]{2}{*}{ Competency } & \multicolumn{2}{|c|}{$\begin{array}{l}\text { Surgeons } \\
(n=100) \\
\end{array}$} & \multicolumn{2}{|c|}{$\begin{array}{l}\text { Internists } \\
(n=102)\end{array}$} \\
\hline & rank & Mdn & rank & Mdn \\
\hline Responsibility & 1 & 5 & 1 & 5 \\
\hline Teamwork and collegiality & 2 & 5 & 3 & 4 \\
\hline $\begin{array}{l}\text { Knowing and maintaining own } \\
\text { personal bounds and possibilities }\end{array}$ & 3 & 5 & 5 & 4 \\
\hline Empathy and openness & 4 & 4 & 4 & 4 \\
\hline $\begin{array}{l}\text { Structure, work planning and } \\
\text { priorities }\end{array}$ & 5 & 4 & 2 & $5^{a}$ \\
\hline Coping with mistakes & 6 & 4 & 7 & 4 \\
\hline Active listening to patients & 7 & 4 & 8 & 4 \\
\hline $\begin{array}{l}\text { Scientifically and empirically } \\
\text { grounded method of working }\end{array}$ & 8 & 4 & 6 & 4 \\
\hline $\begin{array}{l}\text { Verbal communication with } \\
\text { colleagues and supervisors }\end{array}$ & 9 & $4^{a}$ & 10 & 3 \\
\hline Ethical awareness & 10 & 4 & 9 & 4 \\
\hline Advising patients & 11 & 3 & 13 & 3 \\
\hline Safety and risk management & 12 & 3 & 14 & 3 \\
\hline Active professional development & 13 & 3 & 11 & 3 \\
\hline Coping with uncertainty & 14 & 3 & 12 & 3 \\
\hline $\begin{array}{l}\text { Handling emotions of patients } \\
\text { and their relatives }\end{array}$ & 15 & 3 & 15 & 3 \\
\hline Adapted informing of patients & 16 & 3 & 18 & 3 \\
\hline $\begin{array}{l}\text { Respecting privacy and autonomy } \\
\text { of the patient }\end{array}$ & 17 & 3 & 16 & 3 \\
\hline $\begin{array}{l}\text { Attention to individual patient } \\
\text { background }\end{array}$ & 18 & 3 & 17 & 3 \\
\hline Attention to relatives and caregivers & 19 & 2 & 20 & 2 \\
\hline $\begin{array}{l}\text { Written (and digital) account/report to } \\
\text { colleagues and supervisors }\end{array}$ & 20 & 2 & 19 & 2 \\
\hline Continuity in the care process & 21 & 2 & 22 & 2 \\
\hline $\begin{array}{l}\text { Attention to psychosocial aspects } \\
\text { of health problems }\end{array}$ & 22 & $2^{\mathrm{a}}$ & 23 & 2 \\
\hline Role differentiation & 23 & 1 & 21 & 2 \\
\hline Active health promotion & 24 & 1 & 24 & 1 \\
\hline Financial and social awareness & 25 & 1 & 25 & 1 \\
\hline
\end{tabular}

${ }^{a} p<.05 ;$ ranks $1-10$ are marked in bold

by male and female physicians [28]. Furthermore, in a study among junior faculty, physicians on role models for physician-scientists, women attributed more importance to communication and management abilities in their role models, whereas male physicians envisioned scientific knowledge as important in their role models [29]. These gender differences in the ranking of competencies for first year residents might be relevant for more gender specific training during residency, e.g. more communication training for male residents and more training in scientific work for female residents.
Table 5 Ranking order of the 25 competencies by all participating women and men

\begin{tabular}{|c|c|c|c|c|}
\hline \multirow[t]{2}{*}{ Competency } & \multicolumn{2}{|c|}{$\begin{array}{l}\text { Women } \\
(n=57)\end{array}$} & \multicolumn{2}{|c|}{$\begin{array}{c}\text { Men } \\
(n=143)\end{array}$} \\
\hline & rank & Mdn & rank & Mdn \\
\hline Responsibility & 1 & 5 & 1 & 5 \\
\hline $\begin{array}{l}\text { Structure, work planning and } \\
\text { priorities }\end{array}$ & 2 & $5^{\mathrm{b}}$ & 5 & 4 \\
\hline $\begin{array}{l}\text { Knowing and maintaining own } \\
\text { personal bounds and possibilities }\end{array}$ & 3 & 5 & 3 & 4 \\
\hline Teamwork and collegiality & 4 & 4 & 2 & 4 \\
\hline Empathy and openness & 5 & 4 & 4 & 4 \\
\hline $\begin{array}{l}\text { Verbal communication with } \\
\text { colleagues and supervisors }\end{array}$ & 6 & $4^{\mathrm{b}}$ & 13 & 3 \\
\hline Active listening to patients & 7 & 4 & 9 & 4 \\
\hline Coping with mistakes & 8 & 4 & 7 & 4 \\
\hline Ethical awareness & 9 & 3 & 8 & 4 \\
\hline Coping with uncertainty & 10 & 3 & 16 & 3 \\
\hline $\begin{array}{l}\text { Scientifically and empirically } \\
\text { grounded method of working }\end{array}$ & 11 & 3 & 6 & $4^{b}$ \\
\hline Advising patients & 12 & 3 & 10 & 3 \\
\hline Safety and risk management & 13 & 3 & 11 & 3 \\
\hline $\begin{array}{l}\text { Handling emotions of patients } \\
\text { and their relatives }\end{array}$ & 14 & 3 & 14 & 3 \\
\hline Active professional development & 15 & 3 & 12 & 3 \\
\hline Adapted informing of patients & 16 & 3 & 18 & 3 \\
\hline $\begin{array}{l}\text { Attention to individual patient } \\
\text { background }\end{array}$ & 17 & 3 & 17 & 3 \\
\hline Role differentiation & 18 & 3 & 22 & 1 \\
\hline $\begin{array}{l}\text { Respecting privacy and autonomy } \\
\text { of the patient }\end{array}$ & 19 & 2 & 15 & 3 \\
\hline $\begin{array}{l}\text { Written (and digital) account/report } \\
\text { to colleagues and supervisors }\end{array}$ & 20 & 2 & 20 & 2 \\
\hline Attention to relatives and caregivers & 21 & 2 & 19 & $2^{\mathrm{a}}$ \\
\hline Continuity in the care process & 22 & 2 & 21 & 2 \\
\hline $\begin{array}{l}\text { Attention to psychosocial aspects } \\
\text { of health problems }\end{array}$ & 23 & 2 & 23 & 2 \\
\hline Active health promotion & 24 & 1 & 24 & 1 \\
\hline Financial and social awareness & 25 & 1 & 25 & 1 \\
\hline
\end{tabular}

${ }^{\mathrm{a}} p<.05,{ }^{\mathrm{b}} p<.01$; ranks $1-10$ are marked in bold

A strength of our study is the large number of experienced physicians who participated in the ranking of competencies for the first year of residency. However, the response rate of $21.2 \%$ was only moderate. Furthermore, since only surgeons and internists were included in the study, the generalizability to physicians of other specialties is limited. In addition, women and consultants were underrepresented in our study. Additionally, the number of physicians from the three different medial faculties was different. Despite these limitations, the results of our study are consistent with an earlier study 
with few participants [15] and provide additional information regarding the importance of certain competencies relevant for entrustment decisions in first year residents.

\section{Conclusions}

Physicians from medical faculties with different undergraduate curricula show no differences in the ranking of competencies relevant for entrustment decisions in first year residents. Their focus lies on competencies regarding professional behavior, communication, and patient management. Especially aspects of medical professionalism prevail among the top 10 competencies, like showing responsibility for the work. Differences occur between the perspectives of department directors, consultants, and residents as well as between surgeons and internists and male and female physicians. These differences should be considered carefully in the planning of competence-based postgraduate education programs.

\section{Acknowledgements}

We thank all physicians who participated in this study. For his technical support, we thank Florian Wölfle.

\section{Availability of data and material}

All data and material are available in the manuscript.

\section{Funding}

This study is part of the ÄKHOM-project, funded by the German Ministry of Education and Research (BMBF), reference number: 01PK1501A/B/C.

\section{Consent for publication}

Not applicable.

\section{Authors' contributions}

SF and SH designed the study. SF, KS, JD, and SP coordinated the study and the data acquisition. SF performed the statistical analyses. SF and SH drafted the manuscript. KS, JD, SP, PB, and MK revised the manuscript for important intellectual content. All authors read and approved the final manuscript.

\section{Ethics approval and consent to participate}

The study was performed in accordance with the Declaration of Helsinki and the Ethics Committee of the Chamber of Physicians, Hamburg, confirmed the innocuousness of the study with consented, anonymized, and voluntary participation (PV3649).

\section{Competing interests}

$\mathrm{SH}$ is section editor to BMC Medical Education. All other authors declare that they have no competing interests.

\section{Publisher's Note}

Springer Nature remains neutral with regard to jurisdictional claims in published maps and institutional affiliations.

\section{Author details}

'Department of Internal Medicine, University Medical Center Hamburg-Eppendorf, Hamburg, Germany. ${ }^{2}$ TUM Medical Education Center, School of Medicine, Technical University of Munich, Munich, Germany. ${ }^{3}$ Department of Medical Education and Education Research, Carl von Ossietzky University of Oldenburg, Oldenburg, Germany. ${ }^{4}$ Universitätsklinikum Hamburg-Eppendorf, III. Medizinische Klinik, Martinistr, 52 D-20246 Hamburg, Germany.
Received: 16 June 2017 Accepted: 4 September 2017

Published online: 07 September 2017

\section{References}

1. Ten Cate O, Hart D, Ankel F, Busari J, Englander R, Glasgow N, et al. Entrustment decision making in clinical training. Acad Med. 2016;91:191-8.

2. Hauer KE, Ten Cate O, Boscardin C, Irby DM, lobst W, O'Sullivan PS. Understanding trust as an essential element of trainee supervision and learning in the workplace. Adv Health Sci Educ Theory Pract. 2014;19:435-56.

3. Frank JR, Snell L, Sherbino J, editors. CanMEDS 2015 Physician Competency Framework. Ottawa: Ottwa Royal College of Physicians and Surgeons of Canada; 2015

4. Borleffs $\mathrm{JC}$, Ten Cate O. Competency-based training for internal medicine. Neth J Med. 2004;62:344-6.

5. Kadmon M, Bender MJ, Adili F, Arbab D, Heinemann MK, Hofmann HS, et al. Competency-based medical education: National Catalogue of learning objectives in surgery. Chirurg. 2013;84:277-85. [Article in German]

6. Warren AE, Allen VM, Bergin F, Hazelton L, Alexiadis-Brown P, Lightfoot $K$, et al. Understanding, teaching and assessing the elements of the CanMEDS professional role: canadian program directors' views. Med Teach. 2014:36:390-402.

7. Hauer KE, Soni K, Cornett P, Kohlwes J, Hollander H, Ranji SR, et al. Developing entrustable professional activities as the basis for assessment of competence in an internal medicine residency: a feasibility study. J Gen Intern Med. 2013:28:1110-4.

8. Shah SS, Sapigao FB 3rd, Chun MB. An overview of cultural competency curricula in ACGME-accredited general surgery residency programs. I Surg Educ. 2017;74:16-22

9. Choe JH, Knight CL, Stiling R, Corning K, Lock K, Steinberg KP. Shortening the miles to the milestones: connecting EPA-based evaluations to ACGME milestone reports for internal medicine residency programs. Acad Med. 2016:91:943-50

10. Wijnen-Meijer M, Ten Cate $\mathrm{O}$, van der Schaaf M, Harendza S. Graduates from vertically integrated curricula. Clin Teach. 2013;10:155-9.

11. Lindgren S, Brannstrom T, Hanse E, Ledin T, Nilsson G, Sandler S, et al. Medical education in Sweden. Med Teach. 2011:33:798-803.

12. Wijnen-Meijer M, Ten Cate O, Rademakers JJDJM, van der Schaaf M, Borleffs JCC. The influence of a vertically integrated curriculum on the transition to postgraduate training. Med Teach. 2009;31:e528-32.

13. Wijnen-Meijer M, Ten Cate O, van der Schaaf M, Burgers C, Borleffs J, Harendza S. Vertically integrated medical education and the readiness for practice of graduates. BMC Med Educ. 2015;15:229.

14. Griewatz J, Wiechers S, Ben-Karacobanim H, Lammerding-Koeppel M. Medical teachers' perception of professional roles in the framework of the German National Competence-Based Learning Objectives for undergraduate medical education (NKLM) - a multicenter study. Med Teach. 2016;38:1157-65.

15. Wijnen-Meijer M, van der Schaaf M, Nillesen K, Harendza S, Ten Cate O. Essential facets of competence that enable trust in medical graduates: a ranking study among physician educators in two countries. Perspect Med Educ. 2013:2:290-7.

16. Wijnen-Meijer M, van der Schaaf M, Nillesen K, Harendza S, Ten Cate O. Essential facets of competence that enable trust in graduates: a delphi study among physician educators in the Netherlands. J Grad Med Educ. 2013;5:46-53.

17. Holmboe ES, Ward DS, Reznick RK, Katsufrakis PJ, Leslie KM, Patel VL, et al. Faculty development in assessment: the missing link in competency-based medical education. Acad Med. 2011;86:460-7.

18. Hampton JR, Harrison MJ, Mitchell JR, Prichard JS, Seymour C. Relative contributions of history-taking, physical examination, and laboratory investigation to diagnosis and management of medical outpatients. BMJ. 1975;2:486-9.

19. Schechter GP, Blank LL, Godwin HA, LaCombe MA, Novack DH, Rosse WF. Refocusing on history-taking skills during internal medicine training. Am J Med. 1996;101:210-6.

20. Horwitz LI, Jenq GY, Brewster UC, Chen C, Kanade S, van Ness PH, et al. Comprehensive quality of discharge summaries at an academic medical center. J Hosp Med. 2013:8:436-43.

21. Unnewehr M, Schaaf B, Marev R, Fitch J, Friederichs H. Optimizing the quality of hospital discharge summaries-a systematic review and practical tools. Postgrad Med. 2015;127:630-9.

22. Barsky AJ. Forgetting, fabricating, and telescoping. Arch Intern Med. 2002;162:981. 
23. West AF, West RR. Clinical decision-making: coping with uncertainty. Postgrad Med J. 2002;78:319-21.

24. Wegwarth O, Gaissmaier W, Gigerenzer G. Smart strategies for doctors and doctors-in-training: heuristics in medicine. Med Educ. 2009;43:721-8.

25. Muller-Juge V, Cullati S, Blondon KS, Hudelson P, Maitre F, Vu NV, et al. Interprofessional collaboration on an internal medicine ward: role perceptions and expectations among nurses and residents. PLoS One. 2013;8:e57570

26. Nagpal K, Arora S, Vats A, Wong HW, Sevdalis N, Vincent C, Moorthy K. Failures in communication and information transfer across the surgical care pathway: interview study. BMJ Qual Saf. 2012;21:843-9.

27. Russ S, Rout S, Sevdalis N, Moorthy K, Darzi A, Vincent C. Do safety checklists improve teamwork and communication in the operating room? A systematic review. Ann Surg. 2013;258:856-71.

28. Lagro-Jannsen AL. Medicine is not gender-neutral: influence of physican sex on medical care. Ned Tijdschr Geneeskd. 2008;152:1141-5. [Article in Dutch]

29. Bakken LL. Who are physician-scientists' role models? Gender makes a difference. Acad Med. 2005;80:502-6.

Submit your next manuscript to BioMed Central and we will help you at every step:

- We accept pre-submission inquiries

- Our selector tool helps you to find the most relevant journal

- We provide round the clock customer support

- Convenient online submission

- Thorough peer review

- Inclusion in PubMed and all major indexing services

- Maximum visibility for your research

Submit your manuscript at www.biomedcentral.com/submit
Biomed Central 